


Two cases of venereal syphilis from the cemetery of the Igreja do Convento do Carmo (Lisboa)
Autor(es):
Codinha, Sónia

Publicado por: CIAS - Centro de Investigação em Antropologia e Saúde

URL persistente:

URI:http://hdl.handle.net/10316.2/41261

DOI:

DOI:http://dx.doi.org/10.14195/2182-7982_19_3

Accessed : $\quad$ 26-Apr-2023 13:50:12

A navegação consulta e descarregamento dos títulos inseridos nas Bibliotecas Digitais UC Digitalis, UC Pombalina e UC Impactum, pressupõem a aceitação plena e sem reservas dos Termos e Condições de Uso destas Bibliotecas Digitais, disponíveis em https://digitalis.uc.pt/pt-pt/termos.

Conforme exposto nos referidos Termos e Condições de Uso, o descarregamento de títulos de acesso restrito requer uma licença válida de autorização devendo o utilizador aceder ao(s) documento(s) a partir de um endereço de IP da instituição detentora da supramencionada licença.

Ao utilizador é apenas permitido o descarregamento para uso pessoal, pelo que o emprego do(s) título(s) descarregado(s) para outro fim, designadamente comercial, carece de autorização do respetivo autor ou editor da obra.

Na medida em que todas as obras da UC Digitalis se encontram protegidas pelo Código do Direito de Autor e Direitos Conexos e demais legislação aplicável, toda a cópia, parcial ou total, deste documento, nos casos em que é legalmente admitida, deverá conter ou fazer-se acompanhar por este aviso.

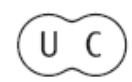


Antropologia Portuguesa

Volume $19 \cdot 2002$

Departamento de Antropologia | Universidade de Coimbra 


\section{Two cases of venereal syphilis from the cemetery of the Igreja do Convento do Carmo (Lisboa)}

\section{Sónia Codinha}

Departamento de Antropologia

Universidade de Coimbra

3000-056 Coimbra, Portugal

soniacodinha@yahoo.com

Abstract The cemetery in the ruins of the Igreja do Convento do Carmo, in Lisbon, is exceptional for the large number of individuals $(n=150)$ recovered from it. This cemetery had been used for approximately three centuries, from the $16^{\text {th }}$ century until the terrible 1755 earthquake which completely ruined the church and a great part of Lisbon. Among the various pathological cases identified during the fieldwork are two cases of venereal syphilis. The two adult skeletons, a female and a male, present lesions that indicate venereal syphilis in almost all parts of their skeletons. The cases are discussed within the context of their chronology and provenience.

Key words Cemetery; adult; venereal syphilis; Lisboa; Portugal.

Resumo O cemitério das ruínas da Igreja do Convento do Carmo em Lisboa evidencia-se pelo grande número de indivíduos recuperados $(n=150)$. O período de utilização deste cemitério foi de aproximadamente três séculos, desde o século XVI até ao terrível terramoto de 1755 que destruiu completamente a igreja e grande parte de Lisboa. De entre as várias patologias identificadas durante o trabalho de campo, esta investigaçāo incidirá sobre dois casos de sífilis venérea. Dois esqueletos adultos, um feminino e o outro masculino, apresentam lesões que apontam para esta patologia. Os casos foram discutidos no contexto da sua cronologia e proveniência.

Palavras-chave Cemitério; adulto; sifílis venérea; Lisboa; Portugal. 


\section{Introduction}

The origin of the human treponematoses has long been debated, with a vast literature devoted to this important question. Basically, four theories make up this controversy. The Pre-Columbian Theory states that human treponematosis were present, though unrecognised, in the Old World before the return of Columbus and his crews from their first voyage to the New World. It has been argued that the disease was not distinguished from leprosy at least until $1500 \mathrm{AD}$ (Steinbock, 1976). Another version of this theory sees venereal syphilis as a late occurrence, first manifesting itself in the urbanised areas of Europe at the beginning of the Renaissance (Cockburn, 1961 in Meyer et al., 2002). The other treponematoses were probably present long before that era and may have undergone parallel evolution leading to venereal syphilis more than once in suitable conditions (Brothwell, 1970 in Meyer et al., 2002).

The Columbian Theory argues that the crews of Columbus brought the pathogen of venereal syphilis to Europe in 1493. Lack of resistance against the newly imported Treponema pallidum led to widespread infection of almost all European populations in only few years (Baker and Armelagos, 1988).

The Unitarian Theory proposed by Hudson (1965) claims that all of the treponematoses form in fact a gradient of symptoms of a single disease which manifests itself differently in response to different local environments. The modern syndromes of treponematosis present a continuum from the superficial lesions of pinta at one extreme to the pathological damage to deep body structures caused by venereal syphilis at the opposite extreme (Crosby, 1969; Steinbock 1976).

The Alternative Theory sees Africa as a possible source of the disease. Contact between European and African populations had been established for millennia, so that treponemal pathogens could have been introduced into Europe long before $1492 \mathrm{AD}$ (Livingstone, 1991).

Treponematosis is rare in the Portuguese archaeological record. The previously reported cases consist of a right femur and 
fibula (probably from the same individual) from an ossuary (c. 1500-1800 AD) in the second Chapel of the Epistle in the Igreja do Convento do Carmo (Lopes and Cardoso, 2000), and the cranium n. 282 from the Identified Crania Collection of the Medical Schools [Coleçño de Crânios Identificados - Escolns Médicas] of the Anthropological Museum at the University of Coimbra [previously misidentified as part of the Identificd Skeleton Collection]. This cranium presents caries sicca on the frontal and both parietal bones (Santos, 2000), and "hypertrophic cirrhoses of the liver" is registered as the cause of death of the female, 28 years old, who died in 1899 at Lisbon. In this paper, two complete skeletons (burial 61 and 124) recovered from the cemetery of the ruins of Igreja do Convento do Carmo, in Lisbon show pathology characteristic of treponematosis. Although it is difficult to distinguish among the different types of treponematosis from bone lesions alone because the pathological differences are merely quantitative with considerable overlapping between the syndromes (Steinbock, 1976), the adult age of the skeletal individuals, the severity of the bone lesions, and the chronology and provenience of the burials point to a diagnosis of venereal syphilis.

\section{Materials and methods}

In the end of August of 2001, during excavations for the construction of a new staircase in front of the ruins of the Igreja do Convento do Carmo, human skeletal remains were uncovered. In order to proceed with the excavation of that area, an emergency intervention was organised by the archaeologist António Marques from the Dioisĩo de Museus e Palácios da Cidade de Lisbon. The author, a physical anthropologist at the Department of Anthropology of the University of Coimbra, collaborated in the excavation and recovery of the human remains.

Although only the construction area was excavated, 150 individual burials plus 19 ossuaries were recovered. The inhumations had all been made directly in the ground without any 
kind of funerary structure, with few artifacts recovered (a bracelet, some earrings, a ring, and a rosary, all made of inexpensive materials). Historical records confirmed that people from the lowest social classes were buried in this cemetery, one of the most popular of its time. It was in use from the $16^{\text {th }}$ century until the earthquake of 1755 which ruined the church (Marques, 2001). The majority of the burials show an east-west orientation, with the head to the west in accordance with the Christian belief in the resurrection of the body. The recovered individuals represent both sexes and all ages, ranging from foetuses to old individuals.

Burials 61 and 124 described in this paper were exceptional due to the severe bone pathology throughout their skeletons, particularly the cranial vault lesions known as caries siccn, considered pathognomonic for venereal syphilis (Virchow, $1896 \mathrm{in}$ Aufderheide and Rodríguez-Martín, 1998). The age-at-death determination for burial 61 was based on the appearance of the auricular surface of the ilium developed by Lovejoy et al. (1985). For sex determination, the recommendations of Ferembach et al. (1980) and the metric analysis developed by Wasterlain (2000) were followed. The estimation of stature was calculated in accordance with the formula developed by Olivier and Tissier (1975).

\section{Description of the remains}

\section{Burial 61}

This burial represents a female more than 30 years of age at death, with a stature estimate of $150 \pm 2.8 \mathrm{~cm}$. Besides the severe widespread bone lesions that involve both the cranial and postcranial skeleton, this individual presents a Colle's fracture (Ortner, 2003) of the distal left radius. The skeleton is relatively well preserved, although the left femur, tibiae and fibula are missing, probably due to prior disturbances in the burial area.

The frontal, both parietals, and the occipital exhibit on the external table gummatous lesions characterised by a mixture of bone formation and destruction. This creates a "worm-eaten" 
appearance (Figure 1), which is consistent with caries siccn (Ortner, 2003). Some of these lesions perforated the cranial vault to the inner table. In the right half of the mandible, tenuous signs of active periostitis are visible.

Almost all of the bones from the post-cranial skeleton (except the vertebrae, sacrum, both radii, right ulna, hands and feet) exhibit signs of infection, with the clavicle, humerus, tibia, and femur being the most affected. None of the articular Convento do Carmo, showing caries sicca. surfaces are involved. In the clavicles and scapulae, the osteolytic lesions are asymmetrical, being more severe on the left side. These are localized on the acromial extremity of the clavicle and on the inferior part of the acromion process. Both humeri present nongummatous periostitis in the form of elevated exostoses, restricted to the proximal third of the diaphysis (Figure 2). The left ulna shows mild porosity in the area near the brachial tuberosity. Although the ribs were very fragmented, some fragments from both sides revealed porosity accompanied by thickening of the affected areas.

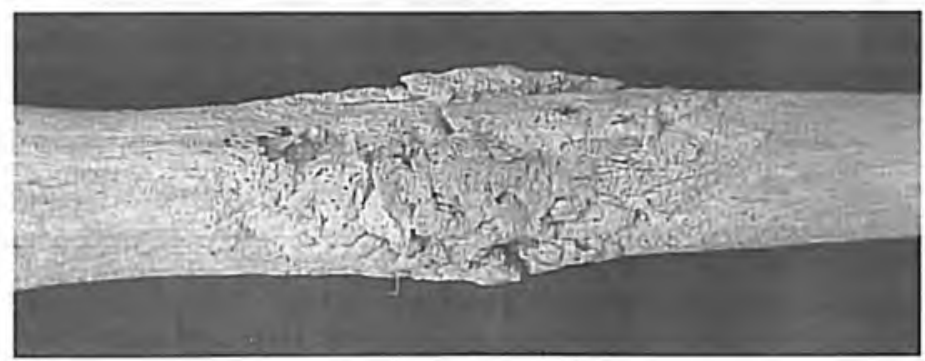

Figure 2. Proximal third of right humerus of burial 61 , from Igreja do Convento do Carmo, showing nongummatous periostitis in the form of elevated exostoses. 




Figure 3. Distal third of burial 61 femur diaphysis with irregular new bone formation.

Periosteal reactive bone occurs on the diaphysis adjacent to the femoral greater trocanter. There is also an area of irregular new bone on the lower shaft (Figure 3). The anterior aspects of the proximal tibiae diaphyses are expanded, giving rise to the curvature commonly known as "sabre-shin". Furthermore, on the lateral shafts near the proximal extremity we can see periosteal apposition of new bone.

\section{Burial 124}

The individual exhumed from this burial has been identified as a male. Since the most useful bones to determine age at death were very fragmented, it can only be said that this individual was an adult at time of death. His estimated stature was about $174.67 \pm 3.56 \mathrm{~cm}$.

Although the cranium

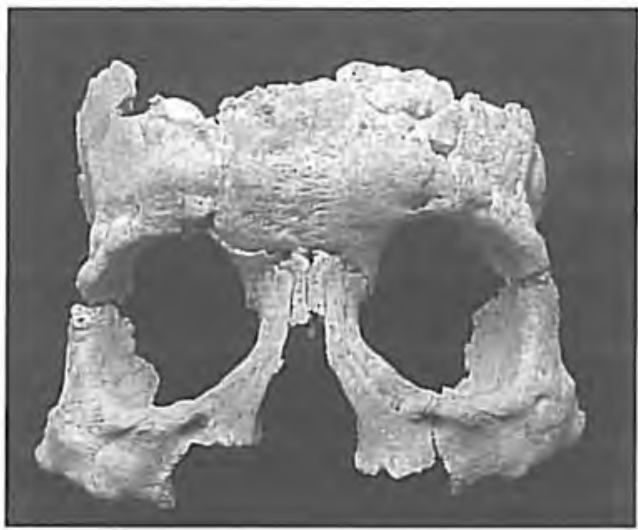

Figure 4. Facial bones of burial 124. Note the signs of development of the typical caries sicca in the frontal bone. is very fragmented, after partial reconstruction the active superficial lesions of caries siccn with hyperostosis became apparent on the frontal and parietal bones. The zygomatic bones and the naso-palatine areas are also affected (Figure 4). The mandible presents thickening and slight porosity from the deposition of new bone. 
Severe osteolytic lesions are seen in the extremities of both clavicles with enlargement and erosion of the corresponding areas on the acromions. In some rib fragments are seen deposits of new bone on both the internal and external aspects. The cartilage connecting the left first rib to the manubrium appears to be ossified, but the right first rib is not observable. The inferior portion of the sternal body shows osteolytic lesions in the anterior and posterior aspects.

Both humeri present pronounced cortical thickening with proliferation of new bone, but the articular extremities are not affected (Figure 5). Both the radii and ulnae are extremely fragmented, and the broken ends reveal cortical thickening and

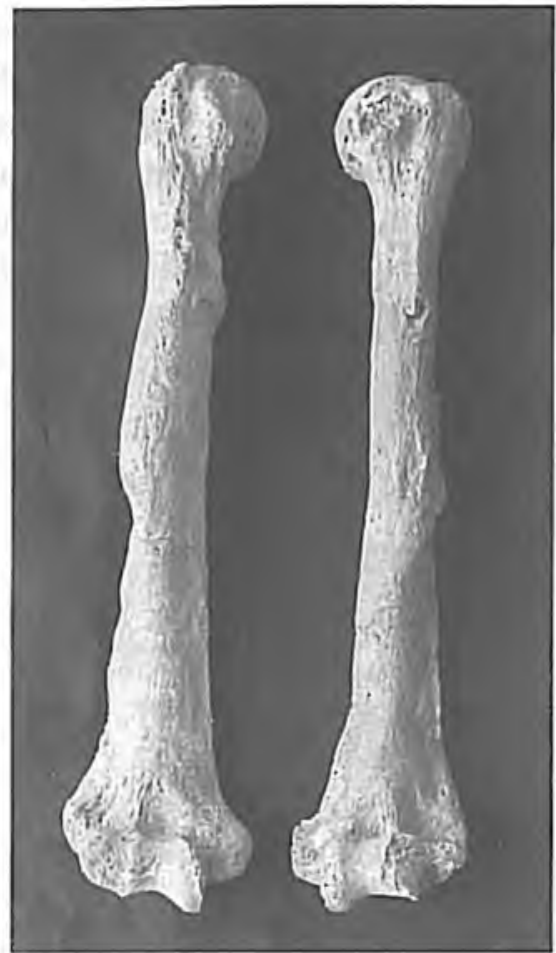

Figure 5 . Humeri of burial 124 showing cortical thickening. medullar cavity obstruction. The right ulna has a large osteolytic lesion in the distal extremity, and the left ulna shows the formation of gummas in the proximal shaft of the diaphysis.

The vertebrae are also very fragmented and, except for the cervical vertebrae described here, no signs of infection were detected. C2 and C3 are linked together by irregular porous vertical growths on the anterior surfaces of the vertebral body and around the facets. C4, C5 and C6 are completely ankylosed, with notable collapse of $C 5$. Although vertebral pathology may not be related to the treponemal infection. Osteolytic lesions are present in the trapezium and capitate, more clearly visible in the latter bone.

The femora present cortical thickening, with a rugose appearance (Figures $6 \mathrm{~A}$ and B). Apparently the entire periosteum 
became inflamed and the subperiosteal response resulted in the thickening and deformation of the involved bone. By comparison, the tibiae are more mildly affected by periosteal reactive bone. The fibulae present the most striking bone reactions, with extensive formation of periosteal new bone and bony bridging over the blood vessels (Figures 7A and $B$ ).

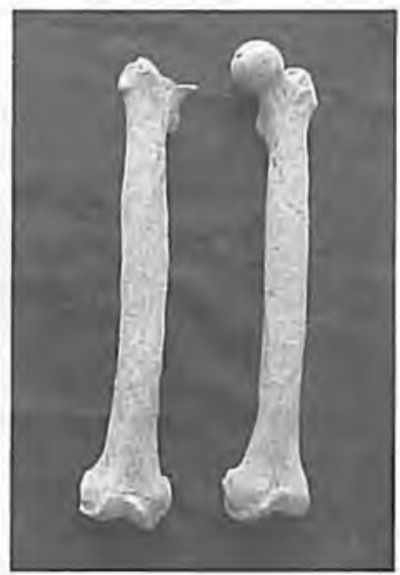

A

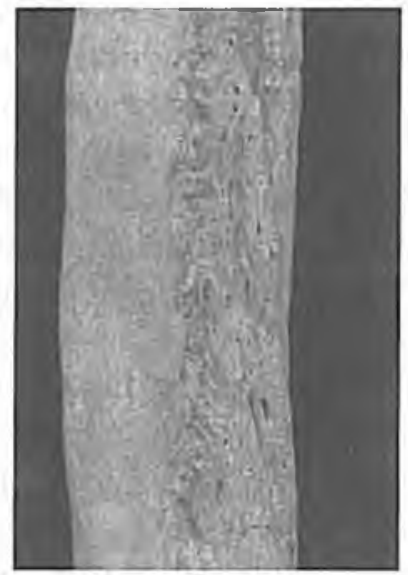

B

Figure 6. A. Femora from burial 124. B. Close-up view of the posterior proximal part of the diaphysis of burial 124 .

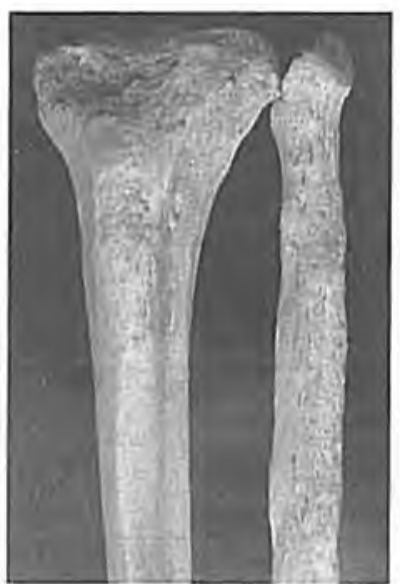

A



B

Figure 7. A. Proximal shaft of the diaphysis of the left tibiae and fibulae of 124 . Notice the differences between the severity of the bone lesions. B. Posterior view of the medial diaphysis of the left fibula with bony bridging. 


\section{Discussion}

The bone lesions caused by syphilis often resemble those of other infections, hereditary disorders and neoplastic processes, thus the necessity for careful differential diagnosis (Steinbock, 1976). Both skeletons show remodelled osteolytic lesions of the cranial vault. Destructive skull lesions may develop in multiple myeloma or metastic carcinoma, but the lesions associated with tumors are smaller, not totally necrotic, and are accompanied by little if any bone regeneration (Steinbock, 1976).

In the appendicular skeletons, osteolytic lesions, narrowing of the medullary canals of some long bones by endosteal remodelling, cortical thickening, and plaques of striated and porous unremodeled new bone are evident in both skeletons, except for the tibiae of burial 124.

Skeletal syphilis has often proved difficult to distinguish from skeletal tuberculosis (Aufderheide and Rodríguez-Martín, 1998). In tuberculosis, destruction of bone tissue predominates with very little new bone formation, but in these two cases, cortical thickening from subperiosteal bone apposition and multifocal skeletal involvement are the rule. Although in burial 124 some vertebrae are affected, in contrast to tuberculous spondylitis, the cervical spine is involved and paravertebral abscesses are absent. Additionally, in both cases there is no involvement of the joints, a frequent site for extrapulmonary tuberculosis (Steinbock, 1976; Ortner, 2003).

Florid new bone formation with bony bridging can be seen on the surfaces of the humerus and femur diaphyses of burial 61, and in the fibulas of burial 124. In the latter case, gummas are visible in some long bones, but the margins of the defects are not smooth and sclerotic as in the cloacae of osteomyelitis. Gummatous osteoperiostitis must not be confused with the suppurative cloacae and sequestra of hematogenous or pyogenic osteomyelitis, which are absent in these cases (Steinbock, 1976; Aufderheide and Rodríguez-Martín, 1998; Ortner, 2003).

Fortunately, there are certain features such as the presence of caries sicco in the cranial vault and expansion with superficial cavitation in the long bones that are pathognomonic of treponemal 
infection (Hackett, 1976). Bone lesions in syphilis are bilateral, widespread and periosteal in nature, with gradual merging of the new bone and the underlying cortex, leading to the ultimate loss of the boundary line between the two (Hackett, 1976). Because these lesions are seen in both skeletons, a diagnosis of syphilis seems fairly secure.

But if the differential diagnosis points to syphilis, which kind are we dealing with here, endemic or venereal? The chronology, provenience, and age at death of both individuals, plus the severity and distribution of bone lesions, all suggest venereal syphilis. Tertiary syphilitic bone lesions are characterised by an excessive osteosclerotic response to the infection, gummatous destruction, and perifocal osteosclerotic reaction involving the periosteum and the underlying bone (Ortner, 2003). All of these forms of pathology can be found in the affected bones of both skeletons, making the diagnostic of venereal syphilis quite reasonable.

\section{Conclusions}

The origin and subsequent spread of venereal syphilis throughout the world is a controversial issue, and this question is far from being solved, partly because of the lack of archaeological cases in Europe. On the other hand, historical documents do describe the occurrence by 1500 of an epidemic "new" disease which has been identified with venereal syphilis (Baker and Armelagos, 1988). Despite the fact that there are different theories to explain the origin of syphilis, there is some measure of agreement about the typical circumstances that promote the spread of venereal syphilis. This form of the disease is associated with the higher population density of cities and the development of certain cultural patterns: greater attention to personal hygiene, more protective clothing, the use of individual eating utensils, and separate sleeping quarters for individuals. All of these factors would have favoured the survival of a strain of treponemes that could be spread by venereal transmission and not only through direct skin-to-skin transmission. The provenience of the two cases reported here fit what seems to be the typical context for the development and 
spread of venereal syphilis. Lisbon was one of the most important commercial harbours in Europe during the $15^{\text {th }}-18^{\text {th }}$ centuries because the Portuguese were in the forefront of exploration of new realms, a situation that provided a great deal of interaction between peoples from different parts of the world.

Although there are historical references to outbreaks of syphilis in Portugal (Rodrigues, 1990) during this time, venereal syphilis is a rare condition in the Portuguese archaeological record. In fact, these two individuals are, at this time, the only complete skeletons known with this pathological diagnosis. This makes them very important for our understanding of the paleopathology of past Portuguese populations. Because these cases involve relatively well preserved adult skeletons, one of each sex, with differences in the nature and severity of their bone lesions, they are particularly valuable for comparison with future cases that may be discovered, as they provide a good example of the different impact of the same pathogenic agent on different individuals.

\section{Acknowledgments}

António Marques from the Divisño de Museus e Palácios da Cidade de Lisbon.

\section{Bibliography}

Aufderheide, A. C.; Rodríguez-Martín, C. 1998. The Cambridge Encyclopedin of Human Palcopathology. Cambridge, Cambridge University Press.

Baker, B. J.; Armelagos, G. J. 1988. The origin and antiquity of syphilis: paleopathological diagnosis and interpretation. Current Anthropology, 29(5):703-737.

Crosby Jr., A. W. 1969. The early history of syphilis: A reappraisal. American Anthropologist, 71(2): 218-227.

Ferembach, D.; Schwidetzky, I.; Stloukal, M. 1980. Recommendations for age and sex diagnoses of skeletons. Joumnl of Human Erolution, 9(7): 517-549.

Hackett, C. J. 1976. Dingnostic criteria of syphilis, yaws and treponarid (Treponematoses) and of some other disenses in dry bones. Sitzungsbericht 
der Heidelberger Akademie der Wissenschaften Mathematischnaturwissenschaftliche Klasse, Abhandlung 4. Berlin, Springer-Verlag. Hudson, M. D. 1965. Treponematosis and Man's social evolution. American Anthropologist, 67(1): 885-901.

Livingstone, F. B. 1991 . On the origin of syphilis: an alternative hypothesis. Current Anthropology, 32(5): 587-590.

Lopes, L. A.; Cardoso, H. F. V. 2000. Possível caso de sífilis em fémur e tíbia direitos de um indivíduo proveniente do carneiro da segunda capela da epístola do Convento do Carmo de Lisboa (Sécs. XVI-XIX?). In: Actas do $3^{\prime \prime}$ Congresso de Arqucologin Peninsular. Vila Real, 1999. Porto, ADECAP. Vol 9: Contributos das ciências e das tecnologias para a arqueologia da Península Ibérica: 459-468.

Lovejoy C. O.; Meindl, R. S.; Pryzbeck, T. R.; Mensforth, R. P. 1985. Chronological metamorphosis of the auricular surface of the ilium: a new method for determination of adult skeletal age at death. American Joumal of Plyysical Anthropology, 68(1): 15-28.

Marques, A. 2001. Personal communication, November. [Unpublished].

Meyer, C.; Jung, C.; Khol, T.; Poenicke A.; Poppe, K.; Alt, W. 2002. Syphilis 2001 - a paleopathological reappraisal. Homo, 53(1):39-58.

Olivier, G.; Tissier, H. 1975. Détermination de la stature et de la capacité cranienne. Bulletins et Mémoires de la Société d'Anthropologic de Paris, n. s., 2(13): 1-11.

Ortner, D. J. 2003. Identification of palcopnthological conditions in human skeletnl remains. $2^{\text {nd }}$ edition. San Diego, Academic Press.

Powell, M. L. 1993. Treponematosis before 1492 in the southeastern United States of America: Why call it syphilis? In: Dutour, O.; Pálfi, G.; Derato, J.; Brun, J. P. (eds.). L'origine de la syphilis en Europe nunnt ou après 1493? Actes du colloque international de Toulon. Paris, Éditions Érrance: 158-163.

Rodrigues, T. 1990. Crises de mortalidade em Lisboa. Séculos XVI e XVII. Lisboa, Livros Horizonte.

Santos, A. L. 2000. A skeletal picture of tuberculosis. Macroscopic, radiological, biomolecular; and historical evidence from the Coimbra Identified Skeletal Collection. Dissertação de Doutoramento em Antropologia Biológica, Departamento de Antropologia, Universidade de Coimbra. [Unpublished]. Steinbock, R. T. 1976. Paleopathological dingnosis and interpretation. Bone disenses in ancient human populations. Springfield, Charles Thomas Publishers.

Wasterlain, S. 2000. Morphé. Análise das proporçōes entre os membros, dimorfismo sextual e estatura de uma anostra da Coleç̧̃o de Esqueletos Identificados do Museu Antropológico da Lniversidade de Coimbra. Dissertação de Mestrado em Evolução Humana, Departamento de Antropologia, Universidade de Coimbra. [Unpublished]. 